\title{
PEMBUATAN HAND SANITIZER UNTUK MENCEGAH/MELINDUNGI DIRI DARI PENYAKIT COVID-19
}

\author{
Efi said Ali ${ }^{1 *}$, Asmara sari Nasution ${ }^{2}$, Sinto ${ }^{3}$ \\ ${ }^{1,2}$ Agroteknologi, Fakultas Pertanian, Universitas Al-Azhar, Jl. Pintu Air IV No.214 Kwala Bekala \\ Padang Bulan Medan \\ ${ }^{3}$ Manajemen, Fakultas Ekonomi, Universitas Al-Azhar, Jl. Pintu Air IV No.214, Kwala Bekala, Kec. \\ Medan Johor, Kota Medan, Sumatera Utara 20143 \\ * efisaidali62@gmail.com
}

\begin{abstract}
ABSTRAK. Telah dilaksanakan kegiatan Pengabdian Masyarakat sebagai salah satu Dharma dari Tri Dharma Perguruan tinggi dengan judul Pembuatan Hand Sanitizer Untuk Mencegah/Melindungi Diri Dari Penyakit Covid-19, yang dilakukan di pesantren/pondok Tahfiz Jamiyah Sholawatan Ahbabun Nabi, Jalan Pasar 1, kelurahan Tanjung Sari, kecamatan Medan Selayang, Kota Medan, kegiatan ini dilaksanakan selama 2 hari mulai tanggal 4 dan 5 September 2021, sasaan kegiatan pengabdian ini adalah para santri, sehingga nantinya akan menjadi ketrampilan bagi santtri untuk membuat Hand Sanitizer, mengingat kegiatan dan aktifitas para santri yang rawan terpapar covid-19 karena kurang nya menjaga Prokes terutama masalah kebersihan tangan, Dari kegiatan ini terlihat antusias dari para santri dan pengasuh nya, dan akhirnya hasil pelatihan diberikan kepada pomdok
\end{abstract}

Kata kunci: : Pengabdian, Hand sanitizer, Covid-19

ABSTRACT. Community Service activities have been carried out as one of the Dharmas of the Tri Dharma of Higher Education with the title Making Hand Sanitizer To Prevent/Protect Yourself From Covid-19 Disease, which was carried out at the Tahfiz Jamiyah Islamic boarding school / Pondok Sholawat Ahbabun Nabi, Jalan Pasar 1, Tanjung Sari village, Medan Selayang sub-district, Medan City, this activity is carried out for 2 days starting on September 4 and 52021 , the target of this service activity is the students, so that later it will become a skill for the students to make Hand Sanitizer, considering the activities and activities of the students who are prone to exposure covid-19 because of the lack of maintaining Prokes, especially the problem of hand hygiene. From this activity, the students and their caregivers seemed enthusiastic, and finally the results of the training were given to the Pomdok

Keywords: Devotion, Hand sanitizer, Covid-19

Terima 22 Januari 2022 Terima dan di revisi 23 Januari 2022 Disetujui 25 Januari 2022

\section{PENDAHULUAN}

Virus Corona atau severe acute respiratory syndrome coronavirus2 (SAR-Cov-2) adalah virus yang menyerang sistem pernafasan, penyakit akibat infeksi virus ini disebut COVID 19. Severe acute respiratory syndrome coronavirus2 (SAR-Cov-2) atau yang dikenal dengan corona adalah jenis baru dari corona virus. Virus ini dapat menyerang siapa saja mulai dari orang dewasa, anak-anak dan bayi, sampai ibu hami; dan menyusui

Pondok Pesantren/Tahfiz Quran Jamiyah Sholawatan Ahbabun Nabi, yang terletak di kelurahan Tanjung sari, kecamatan Medan selayang, kota medan mengasuh kegiatan Tahfiz quran kepada anak anak santrinya, dalam kegiatan beraktifitas sehari hari, siswa/santri berinteraksi denga pihak lain, baik sesama santri maupun dengan pihak lain, situasi ini sangat rawan untuk terjadi nya paparan virus covid-19 terhadap santri dan pengurus yang ada dalam pondok. Untuk mencegah serta menghindari paparan virus covid-19 terhadap santri maupun pengurus maka perlu diberikan informasi kepada mereka tentang perlunya menjaga protokol kesehatam (PROKES), yang salah satunya adalah dengan tetap menjaga kebersihan tangan. Salah satu cara untuk tetap menjaga kebersihan tangan adalah dengan membersihkan tangan dengan bahan Hand 
sanitizer, Persoalan nya adalah mahalnya harga Hand sanitizer ini di pasaran, Sehubungan denga hal tsb perlu di ajarkan kepada mereka cara membuat Hand Sanitizer dengan biaya yang terjangkau sehingga bisa digunakan untuk kegiatan mereka sehari-hari

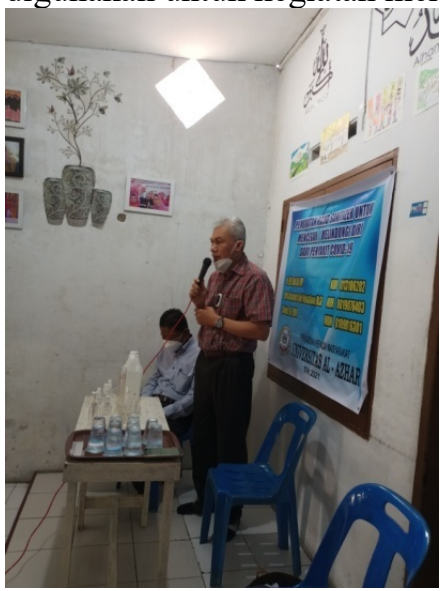

Gambar 1 Ceramah tentang mikroorganisme

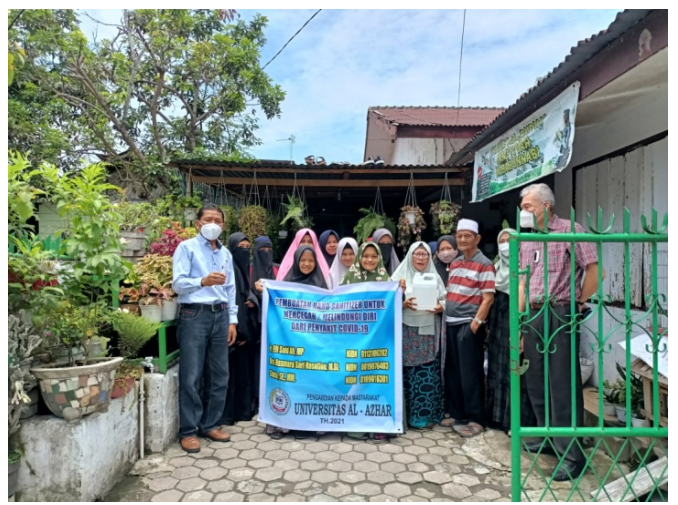

Gambar 2 kegiatan bersama Dosen dan Masyarakat

\section{METODE}

\section{Metode kegiatan Berupa Ceramah dan} Diskusi

Ceramah dan diskusi merupakan cara yang dipakai team pengabdian masyarakat dengan memakai metode $30 \%$ berupa teori dan $70 \%$ berupa praktik langsung, ceramah (pelatihan) diberikan pada peserta. setelah selesai ceramah dilanjutkan dengan diskusi (tanya jawab) dan praktek langsung di lapangan. Materi ceramah yaitu tentang pengenalan bahan bahan yang di gunakan, alat alat yang dipakai dan teknis pembuatan Hand sanitizer

\section{Prosedur Kerja}

Untuk merealisasikan pengabdian masyarakat ini maka dilakukan terlebih dahulu pendekatan kepada pengurus Pondok Pesantren melalui sosisalisasi, Setelah sosialisasi dilakukan ceramah dan pelatihan kepada pengurus Pondok dan Santri. Dalam kegiatan ini juga dilakukan diskusi dan tanya jawab.

\section{Kegiatan}

1. Observasi.

Tim PKM mengumpulkan data dan informasi mengenai permasalahan yang terjadi seperti kegiatan sehari hari santri, keluar masuk orang orang ke dalam pondok dan kebiasaan sehari hari santri dan penghuni pondok Tim PKM melakukan penyuluhan kepada Pengurus pondok dan santri tentang pegertian mikro organisme virus, penularan dan pencegahan dengan menggunakan hand sanitizer

2. Cara pembuatan hand sanitizer

Alat dan bahan: alkohol $99 \%$, hidogen peroksida, air destilasi, gel bila diperlukan untuk hand sanitizer berbentuk gel, gilserol, gelas ukur, jerigen, pengaduk, corong, botol tempat hand sanitizer Cara kerja: Masukkan alkohol terebih dahulu kedalam jerigen, lalu tambahkan hidrogen peroksida ke dalam jerigen, masukkan gliserol, tambahkan 11 air yang telah di distilasi, aduk hingga tercampur dengan rata, bagi isi jergen tadi ke dalam botol ukuran 100 atau $500 \mathrm{ml}$, simpan terlebih dahulu selama 72 jam sebelum digunakan, jauhkan dari paparan sinar matahari, setelah itu hand sanitizer siap digunakan,

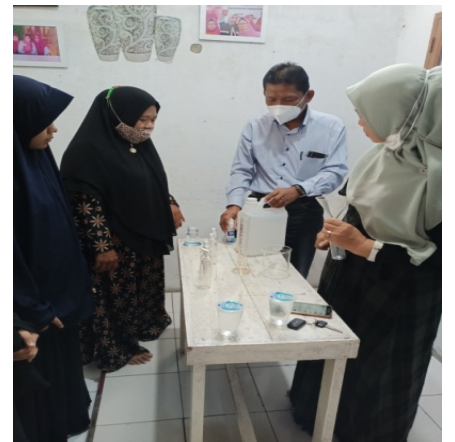

Gambar 3 Pelatihan pengenalan Bahan 


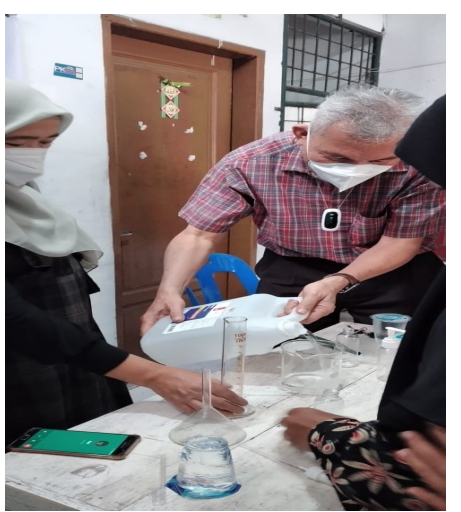

Gambar 4 Latihan pencampuran bahan

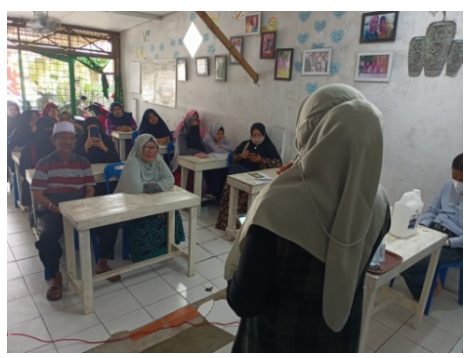

Gambar 5 Ceramah kegunaan Hand sanitizer

\section{HASIL DAN PEMBAHASAN}

Pada Pengabdian Kepada Masyarakat ini memiliki program sebagai berikut:

1. Peserta Pelatihan dikenalkan mengenai Protokol Kesehatan seperti pentingnya menggunakan masker, menjaga jarak dan menjaga kebersihan diri

2. Peserta pelatihan dikenalkan tentang mikro organisme, cara penyebarannya dan antisipasi yang dapat dlakukan agar terhindar dari paparan virus

3. Peserta pelatihan dikenalkan mengenai bahan bahan untuk membuat hand sanitizer dan cara membuat hand sanitizer

Dari kegiatan Pengabdian dapat diketahui bahwa pengenalan kebersihan dan protokol kesehatan perlu diberikan kepada seluruh santri dan para pengasuh, terlihat pada waktu kunjungan, para santri, pengasuh dan pengurus pondok tidak mengikuti protokol kesehatan, seperti tidak memakai masker, tidak mempunyai tempat cuci tangan dan bebas nya para santri berkomunikasi dengan sesama nya tanpa menjaga jarak. Dari kegiatan yang dilakukan juga dapat diketahui kurang nya pemahaman para santri, pengasuh dan pengurus pondok tentang ilmu mikro organisme seperti bakteri dan virus, tentang bagaimana penyebaran virus dan cara penularan nya, sehingga ceramah tentang pemahaman mikro organisme sangat membantu pengetahuan dan pemahaman mereka dan antisipasi terhadap paparan virus Hasil dari kegiatan ini terlihat antusias nya para peserta mengikuti kegiatan ini seperti partisipasi aktif mereka dalam membuat hand sanitizer, kerjasama yang mereka bangun dalam menyelesaikan pekerjaan dan keingin tahuannya dengan banyak nya pertanyaan yang mereka lontarkan

\section{SIMPULAN}

1. Antisipasi dan pecegahan akan paparan virus terutama di musim pandemi sekarang ini sangat berguna bagi mereka dalam kehidupan sehari hari terutama menjaga kebersihan terutama dangan tetap menjaga kebersihan tangan, membunuh kuman yang terbawa di tangan dengan cara mencuci tangan denga air mengalir dan sabun, atau dengan menggunakan alternatif pembersih lainnya seperti menggunaka Hand Santizer

2. Pembuatan Hand sanitizer kepada peserta dapat membantu peserta dalam memahami dan mempraktikkan membuat hand sanitizer di rumah dengan biaya yang lebih ekonomis

\section{UCAPAN TERIMAKASIH}

Dengan selesaikan pengabdian terhadap masyarakat ini di ucapkan banyak terima kasih kepada :

1. Pondok Pesantren/Tahfiz Quran Jamiyah Sholawatan Ahbabun Nabi

2. Kelurahan Tanjung sari, Kecamatan Medan selayang,

3. Universitas Al Azhar Medan

\section{DAFTAR PUSTAKA}

Dewi , D, W, S. Khotimah, and D.F. Liana "Pemmanfaatan Infusa Lidah Buaya (Aloe vera sebagai", vol. 2 p.13

Fatimah, S and S. N. Wardana "kajian Daun Kemanggi (Ocium bacillum) Sebagai Bacterial deactivated Agent (BDA) pada Sintesis Sabun cair Cuci Tangan dari Minyak Jelantah J. Ilm Teknosains vol 5, no 1, p 51, Jul 2019, doi;10.26877/jitek.v5i1. 3544 
Fatimah, S, W. Wiharto, and A. Indra Sari" Ekonomi Kreatif Pembuatan Detergen Cair dan Bubuk pada kelompok PKK Kelurahan Krajan", J. Pemberdaya. Publ. Has pengabdi, kpd. Masy, vol 3, no 2 , p. 199, sep 2019, doi 10.1298/pjp.v312.931

http://conference.unri.ac.id Pembuatan Hand SanitizerSebagai salah satu pencegahan

https://journals2.ums.ac.id edulasi Pembuatan hand sanitizer dari Lidah Buaya dan daun Sirihdi Desa Gilirejo Baru 